\title{
METODOLOGIA EM CIÊNCIA DA RELIGIÃO
}

\author{
Method In the Study Of Religions
}

Fábio L. Stern ${ }^{1}$

Resumo: Este artigo objetiva apresentar alguns pontos que caracterizam metodologicamente a ciência da religião. $\mathrm{O}$ artigo é organizado de modo a discutir inicialmente a história metodológica da ciência da religião e sua tensão disciplinar com outras áreas que também estudam as religiões. A seguir, é apresentada a perspectiva metodológica da ciência da religião: a adoção da perspectiva ética para analisar os conteúdos êmicos. Então, é apresentada a principal fronteira disciplinar da ciência da religião: o agnosticismo metodológico. Finalmente, o artigo encerra com a discussão da teoria do fator de tensão com os fiéis, criada por Michael Pye.

Palavras-chave: Ciência da religião. Metodologia. Êmico e ético. Agnosticismo metodológico. Fator de tensão com os fiéis.

\begin{abstract}
This article aims to present some points that methodologically characterize the study of religion. The article is organized to initially discuss the methodological history of the study of religion and its disciplinary tension with other areas that also research religions. Next, it is presented the methodological perspective of a scholar of religion: the adoption of an etic perspective to analyze the emic discourses. Then, the main disciplinary boundary of the study of religion is presented: the methodological agnosticism. Finally, the article ends with the discussion of the theory of the tension with believers factor, created by Michael Pye.
\end{abstract}

Keywords: Study of religion. Methodology. Emic and etic. Methodological agnosticism. Tension with believers factor.

\section{INTRODUÇÃO}

Esse artigo é uma resposta a um aparente entendimento no Brasil de que não há "metodologia própria" na ciência da religião. Em outro lugar, uma contestação a essa alegação foi apresentada, demonstrando que "mesmo sendo plurimetodológica, a ciência da religião tem suas próprias regras de pesquisa" (STERN, COSTA, 2016, p. 86). Essas regras dizem respeito, em grande parte, a uma postura diferenciada que cientistas da religião assumem, que caracteriza

\footnotetext{
${ }^{1}$ Doutor, mestre e especialista em Ciência da Religião (PUC-SP). Graduando em Ciências da Religião (UFSM). Bolsista PNPD/CAPES pelo PEPG em Ciência da Religião da PUC-SP. E-mail: caoihim@ gmail.com
} 
seus estudos como pertencentes à área, independentemente de quais outros métodos específicos sejam adotados.

Conforme foi mencionado nesse texto ( $c f$. STERN, COSTA, 2016), a criação da ciência da religião enquanto área acadêmica se deu justamente por uma busca por métodos próprios para se estudar as religiões, e as discussões metodológicas são os principais demarcadores de cada fase histórica da disciplina. No Brasil, esse tema se faz ainda mais importante, visto a emancipação institucional entre ciência da religião e teologia ainda ser incipiente, o que às vezes dificulta seu desenvolvimento metodológico, a maturação de uma identidade própria, a abertura de novos cursos e o reconhecimento social dos profissionais cientistas da religião (ENGLER, 2008, p. 276).

A desvalorização da história institucional e de métodos que caracterizam a ciência da religião torna árdua a superação de seus desafios por seus pesquisadores. Há uma década, Steven Engler elencou seis problemas que a disciplina enfrentava no Brasil: (1) a teologia era uma subcomissão da filosofia no Ministério da Educação, e a ciência da religião mal era mencionada em documentos da CAPES, embora estivesse implicitamente compreendida nessa subcomissão; (2) cientistas da religião e teólogos competiam pelas mesmas bolsas, que eram poucas; (3) alguns PPG enfrentavam resistência de administrações e colegas com visão religiosa conservadora; (4) quase nenhum docente dos cursos de ciência da religião possuía titulação em ciência da religião, sendo a maioria deles teólogos²; (5) muitas universidades confessionais viam no caráter não teológico da ciência da religião uma ameaça a ser contida ou uma concorrente a ser cooptada; e (6) as universidades públicas consideravam a ciência da religião muito teológica ou pseudocientífica, não permitindo a criação de novos departamentos ${ }^{3}$ (ENGLER, 2008, p. 276277).

\footnotetext{
${ }^{2}$ Um levantamento efetuado na Plataforma Lattes dos currículos dos professores permanentes dos PPG em ciência da religião do Brasil constatou que até 2017 havia mais doutores em teologia do que em ciência da religião dando aula em programas de ciência da religião: $47 \%$ eram doutores em teologia e $33 \%$ em ciência da religião. Nos PPG em teologia, 83\% eram doutores em teologia e só 6\% eram doutores em ciência da religião (STERN, 2018, p. 85). Embora a isonomia entre as duas disciplinas seja uma busca atual da área na CAPES, na prática isso ainda não se observa no perfil docente desses cursos, cujos números indicam um favorecimento à formação teológica.

${ }^{3} \mathrm{Na}$ verdade a maioria dos cursos de ciência da religião está em universidades públicas no Brasil. O mais correto seria dizer que as instituições de ensino superior, tanto públicas quanto privadas, tendem a possuir ressalvas com a ciência da religião, pois o positivismo é uma marca estruturante na academia brasileira. Usualmente a religião é vista como um objeto sem importância ou de desinteresse científico pelas universidades do país.
} 
Com exceção do primeiro item anterior, quase todas essas questões se mantêm atuais após doze anos. A ciência da religião e a teologia conquistaram sua emancipação da filosofia, e constituíram uma nova área de avaliação na CAPES em 2016, da qual a ciência da religião é epônima. Por um lado, isso foi uma vitória importante a seus programas. Por outro, o fato da teologia e da ciência da religião ainda serem tratadas como a mesma área ( $c f$. CAPES, 2016) pode dificultar a superação dos itens $2,4,5$ e 6 , se os devidos cuidados não forem tomados.

Muitos desses problemas, evidentemente, não são exclusividades brasileiras, aparecendo na ciência da religião de outros lugares ( $c f$. ALLES, 2008). No caso dos países de língua inglesa, onde a nomenclatura da disciplina é ainda mais variada, há problemas bastante complexos ( $c f$. WIEBE, 2005). Talvez o caso mais evidente seja o do termo "history of religions". Atualmente alguns historiadores têm reclamado para si as pesquisas efetuadas com essa nomenclatura desde o final do século XIX. Contudo, uma análise das pesquisas desse período aponta que a metodologia da "history of religions" era muito mais próxima da ciência da religião do que da historiografia (CARVALHO, 2017). Além disso, o próprio Eliade, amplamente apresentado como "historiador" no Brasil, assumiu objetivamente que traduziu o termo alemão Religionswissenschaft (literalmente "ciência da religião") como "history of religions":

Em vista de Religionswissenschaft não ser facilmente traduzível ao inglês, somos obrigados a utilizar "history of religions" em um sentido mais amplo, incluindo não somente a história propriamente dita, mas também o estudo comparado das religiões e das morfologias e fenomenologias religiosas (ELIADE, 1969, p. 1, tradução minha).

É importante ressaltar que quando Eliade escreveu "incluindo não somente a história propriamente dita", ele dizia respeito ao ramo dos estudos empíricos das religiões, da tradicional classificação da disciplina feita por Wach (2018 [1924]). Ainda no início do século XX, Wach dividiu a ciência da religião em duas linhas metodológicas principais: (1) os estudos sistemáticos das religiões, também conhecido como religiões comparadas, e (2) os estudos históricos das religiões, também conhecido como história das religiões. No Brasil, essa segunda linha passou a ser referenciada como "estudos empíricos das religiões" para evitar confusões com a área da história.

Eliade foi um grande crítico do historicismo, tanto que sua obra nada tem de historiográfica; seu trabalho recorre a uma abordagem transcultural por comparações anistóricas. Isso tende a ser ignorado por quem defende que as obras de Eliade são da disciplina de história. 
Mas é claro, não isenta que hoje possa haver uma "história das religiões" metodologicamente inclinada para a disciplina de história, fundamentada na história cultural, o que só complica essa discussão.

Geralmente esses debates ainda não fazem parte dos cursos brasileiros de ciência da religião. Aliás, muitos cientistas da religião no Brasil ainda resistem em traduzir os termos "study of religions" e "history of religions" como "ciência da religião", o que acaba por pulverizar o conhecimento metodológico da área. Isso ocorre ao mesmo tempo em que uma cobrança é feita pelas outras humanidades para que cientistas da religião apresentem "métodos exclusivos" que caracterizem a ciência da religião enquanto uma ciência autônoma, como se fossem claras as fronteiras disciplinares e metodológicas nas ciências humanas.

Nesse texto, tentarei apresentar alguns dos pontos que são mais comumente aceitos sobre métodos que caracterizam a ciência da religião enquanto tal. Como explica Pye (2013, p. 86, tradução minha), “a ciência da religião não possui um único método específico; ao invés disso, ela seleciona um conjunto de métodos apropriados para cada objeto em particular”. Na disciplina, os métodos de coleta e análise de dados podem ser muito diversificados.

De modo amplo, pode-se considerar que a ciência da religião apresenta uma ambiguidade metodológica. Como explica Hanegraaff (2017, p. 207), uma linha de cientistas da religião tende a adotar uma abordagem mais universalista, que busca estabelecer grandes generalizações sobre as religiões (estudo sistemático das religiões), enquanto outro grupo prefere abordagens empiristas de reação contrailuminista, que visam entender cada religião em suas especificidades (estudo empírico das religiões). Traçar pontos de confluência entre essas duas formas antagônicas de se fazer ciência, embora necessário, não é uma tarefa fácil. Portanto, esse texto deve ser visto, acima de tudo, como um convite a maiores esforços nesse sentido.

\section{TENSÕES DISCIPLINARES}

Nascida das discussões de autores como Friedrich Max Müller, Cornelis Petrus Tiele e William Robertson Smith na virada do século XIX para o século XX, a ciência da religião surgiu como uma resposta ao encontro europeu com as religiões dos povos dominados durante a expansão colonialista. Com uma nova proposta acadêmica, originalmente de influência 
iluminista, seus pesquisadores iniciais pretendiam desenvolver métodos empíricos de se estudar as religiões (USARSKI, 2013, p. 51, 56-57).

Seu primeiro foco foram as religiões asiáticas e a tradução de textos sagrados, com grande preocupação em metodologias que tornassem essa nova ciência uma disciplina empírica autônoma da teologia e da filosofia, até então as duas principais formas de se estudar religião na Europa. Essa preocupação em diferenciá-la da teologia e da filosofia é evidente, por exemplo, já na obra de Joachim Wach (2018 [1924]), e também é citada na história da área feita por Eliade, quando ele descreveu um dos primeiros congressos internacionais de ciência da religião, ocorrido na França em 1900, caracterizado por "excluir dos seus trabalhos a filosofia da religião e a teologia" (ELIADE, 1992, p. 5).

A institucionalização da ciência da religião se deu em 1873, anterior a outras áreas que hoje são mais conhecidas (p. ex. sociologia e psicologia). Em 1897, com a disciplina já presente em universidades da Suíça, Países Baixos, França e Bélgica, seu primeiro congresso internacional foi realizado, na Suécia (ELIADE, 1992, p. 5; USARSKI, 2013, p. 58). Contudo, em 1886 a cátedra de Roma foi transformada em história do cristianismo, eivando-a de teologia e dificultando sua autonomia até 1924. Também por conta da teologia a disciplina só apareceu em uma universidade do Reino Unido em 1904, e na Alemanha em 1910 (USARSKI, 2013, p. 56).

Durante essa fase inicial, a disciplina recebeu muitos nomes que viriam a ser depois identificados como sendo ciência da religião (p. ex. "história das religiões", "religiões comparadas", "mitologias comparadas", "estudo das religiões"). O problema é que muitos desses termos também foram utilizados por outras áreas, inclusive pela teologia e pela filosofia, das quais seus fundadores desejavam se distanciar. E conforme outras ciências sociais se firmaram institucionalmente, passaram a reivindicar para si as religiões como objeto de estudo acadêmico, cobrando dos cientistas da religião uma metodologia própria que os identificasse como pertencentes a uma área autônoma.

Uma forma de tentar apaziguar essa tensão foi o desenvolvimento da fenomenologia da religião, criada por Chantepie de La Saussaye e sistematizada por autores como Nathan Söderblom, Gerardus van der Leeuw e Joachim Wach. Esse ainda é o paradigma dominante nos Estados Unidos e na América Latina, em especial pela popularidade de Mircea Eliade, quem foi um forte defensor dessa abordagem. Frente à cobrança de que a ciência da religião deveria ter um 
método próprio que a diferenciasse das outras ciências humanas, os fenomenólogos adotaram uma perspectiva que se mostrava ontológica, considerando que toda religião derivava de um mesmo núcleo comum, "o sagrado", que foi lido por muitos como um elemento metafísico das religiões. Nessa linha de raciocínio, somente os cientistas da religião teriam as ferramentas necessárias para trabalhar com essa categoria cientificamente.

Essa justificativa foi mundialmente utilizada para a abertura de cursos em universidades que já possuíam outras disciplinas que pesquisavam religiões. Conforme citou Murphy (2018, p. 330), a justificativa mais comum nos Estados Unidos para a abertura de programas próprios de ciência da religião era que somente cientistas da religião fariam jus ao estudo integral das religiões, algo que não seria possível se o objeto fosse estudado pela abordagem empíricoreducionista das outras ciências humanas. A noção de que as religiões possuem um "significado único" que precisa igualmente de um "método único" de estudo foi aceita por mais de meio século sem maiores questionamentos, sob a égide de que "ao ler os dados das pesquisas empíricas sobre religiões como 'expressões' desse substrato, seria possível compreendê-las de forma empática, tocando, por assim dizer, a própria subjetividade humana” (MURPHY, 2018, p. 331).

Após a morte de Eliade em 1986, a fenomenologia da religião passou a ser mais questionada. Uma das críticas mais profundas é a acusação de que sua abordagem é colonialista, ou seja, que promove uma valoração das religiões ao classificá-las como mais ou menos "afinadas" ao "sagrado", tendo como ideal de religião o protestantismo alemão. Sua formação discursiva reiteraria e validaria as relações historicamente determinadas de supremacia da Europa sobre os povos que foram colonizados. Isso seria comprovado, por exemplo, nos textos clássicos da fenomenologia da religião, que além de tratarem o cristianismo como a religião mais "evoluída" ou "civilizada", classificam as religiões africanas como "primitivas" e as religiões asiáticas como "místicas” (MURPHY, 2018, p. 335-336, 348).

Outra crítica à fenomenologia da religião diz respeito a seu caráter teológico, que não só ignora os contextos sociais e históricos das religiões, como também se declara um método universal para toda religião, ignorando seus limites hermenêuticos e não refletindo sobre suas próprias implicações confessionais (USARSKI, 2004a; GASBARRO, 2013). Enquanto os fundadores da ciência da religião desejavam se distanciar da teologia e dos estudos não empíricos das religiões, os fenomenólogos beberam de fontes declaradamente teológicas (p. ex. Rudolf 
Otto, Georg W. F. Hegel, Paul Tillich) para construir sua lógica discursiva, adotando uma perspectiva que se distancia, justamente, da empiria.

Outra tentativa de apaziguar a tensão com as ciências humanas foi, conforme explica Mendes (2018), a adoção do termo "ciências" no plural, em uma compreensão de que não existe uma área autônoma, mas um campo disciplinar formado por diferentes disciplinas, as "ciências da religião" (religious studies em inglês). Essa concepção é um complicador em âmbito internacional para o reconhecimento da autonomia de cientistas da religião, pois autoriza diferentes programas de "ciências da religião" a adotar metodologias e epistemologias muito distintas, comportando-se quase como áreas diferentes. Nesse sentido, pode haver tanto cursos amplamente teológicos quanto outros fortemente orientados pela filosofia ou pelas ciências sociais. E todos se consideram como “ciências da religião" (WIEBE, 2005; MENDES, 2018).

Lembrando que um dos pontos elencados por Engler (2008, p. 277) é de que alguns agentes viam na ciência da religião uma concorrente a ser cooptada, a adoção da fenomenologia da religião e do termo no plural parece, em partes, tentar contornar esse problema. Enquanto a fenomenologia da religião aparentemente pacifica a disputa disciplinar com a teologia, inclusive passando a recorrer a conceitos teológicos, a nomenclatura plural parece apaziguar as pretensões de reivindicação do objeto religião pelas outras ciências humanas, introduzindo-as para dentro de seus cursos. Em outras palavras, esses dois pontos - fenomenologia da religião e a nomenclatura no plural - não só permitiram que a filosofia e a teologia, outrora preteridas pelos fundadores da área, fossem reinseridas e hoje façam parte de diversos programas de ciência da religião, como garante a manutenção de nichos protegidos aos sujeitos que primeiro conquistaram o reconhecimento acadêmico e a autorização social de pesquisar sobre as religiões (MENDES, 2018, p. 20). A nomenclatura no plural também retira a necessidade de que a história da disciplina e metodologias desenvolvidas por cientistas da religião sejam ministradas em seus cursos, abrindo lugar às abordagens do que no Brasil tem sido chamado de "disciplinas auxiliares" (história, sociologia, antropologia, filosofia, literatura, psicologia etc.). Isso leva a um círculo vicioso: os próprios egressos acabam por perpetuar noções de que a ciência da religião 
não é uma disciplina autônoma, passam a tratar as disciplinas auxiliares como subdisciplinas da ciência da religião ${ }^{4}$, e quase não leem autores com formação específica em ciência da religião.

Porém, são injustas as cobranças das outras humanidades para que a ciência da religião tenha um "método próprio", pois disciplinas como a antropologia e a sociologia não nasceram sem empréstimos de áreas já estabelecidas. Se tomarmos o caso de Durkheim (1978 [1895]), é claro que uma marca própria foi imposta à sociologia, até porque o fato social foi apresentado como um objeto próprio dessa disciplina. Porém é evidente que a proposta metodológica de Durkheim estava influenciada pelas ciências naturais. Isso não só era tolerado como era esperado no século XIX para que a disciplina fosse considerada acadêmica.

No caso da antropologia, que se institucionalizou mais ou menos na mesma época que a ciência da religião, o foco inicial estava nos métodos comparativos, com influência das taxonomias das ciências biológicas, em uma compreensão de que ao comparar realidades distintas seria possível elaborar leis gerais sobre as culturas ${ }^{5}$. Além disso, é comum uma noção de que não existe um objeto específico na antropologia, porque antropólogos podem estudar qualquer coisa que seja produzida pela humanidade. O que caracterizaria um estudo na antropologia é o seu olhar próprio, o "olhar antropológico".

Mas tanto a antropologia quanto a sociologia fazem aproximações com a história, e hoje a história também utiliza métodos emprestados da sociologia e da antropologia. Uma divisão comumente utilizada para diferenciar essas três áreas foi que a história privilegia o estudo documental, a sociologia trata do fato social das sociedades industriais modernas, e a antropologia estuda os hábitos e a cultura das sociedades. Isso ficou mais evidente no caso da antropologia com Franz Boas e Bronisław Malinowski, quando a pesquisa de campo passou a ser considerada o seu diferencial. Mas com o tempo, várias outras áreas também passaram a recorrer a estudos de campo, e nem por isso viraram subdisciplinas da antropologia.

As cobranças por um método próprio à ciência da religião acontecem porque muitos profissionais que hoje criticam a área entendem que a religião deve ser um objeto de estudo exclusivo deles. Mas nenhuma dessas áreas possui a religião como objeto central, como ocorre

\footnotetext{
${ }^{4}$ Sempre me preocupo com a forma que antropólogos ou psicólogos reagem ao ouvir de cientistas da religião que a antropologia da religião e a psicologia da religião são "subdisciplinas" da ciência da religião. Por mais evidente que seja o absurdo dessa declaração aos profissionais de outras áreas, essa é a concepção de muitos egressos de cursos de ciência da religião no Brasil.

${ }^{5}$ Veja o caso de Frazer (cf. 2005 [1908]).
} 
com a ciência da religião. Um historiador pode passar uma vida inteira sem nunca se debruçar especificamente sobre a religião, e nem por isso deixará de ser reconhecido como historiador. O mesmo se aplica à sociologia ou à filosofia. Mas não dá para fazer ciência da religião sem estudar religião. E assim como a antropologia possui um olhar que caracteriza suas pesquisas, cientistas da religião também possuem uma abordagem própria que define seus estudos.

\section{A DISTINÇÃO ENTRE "ÊMICO” E "ÉTICO"}

O primeiro ponto que caracteriza a atitude metodológica de cientistas da religião frente a seu objeto é a distinção entre discursos êmicos e éticos, com a utilização da perspectiva ética em nossa produção. Essa é a principal ferramenta teórica para salvaguardar a legitimidade científica nas pesquisas da ciência da religião (HANEGRAAFF, 1996, p. 6), e um dos pilares que constituem a própria objetividade acadêmica da disciplina (PLATVOET, 1982, p. 5-6).

Os termos "êmico" e "ético" são oriundos de "phonemics" (fonologia) e "phonetics" (fonética). Portanto, não há qualquer relação com o termo "ética" da filosofia. Para entendê-los, é importante relembrar da linguística. O fonema é a menor unidade sonora que forma uma palavra, e seu estudo é atribuído à fonologia e à fonética. Grosso modo, a fonética estuda a percepção e a forma como os fonemas são produzidos, e a fonologia a sua atribuição de significados. Isso fica evidente com os fonemas da letra "D" no português. Ao passo que no sul do Brasil as palavras "dia" e "dois" são pronunciadas com fonemas distintos para o "D", o fato de quem mora no norte utilizar o mesmo fonema para ambas as palavras não muda o seu significado. Logo, essa é uma diferença importante para a fonética, mas irrelevante para a fonologia. Além disso, um mesmo fonema pode ser representado de formas distintas. Pegando o caso da letra " $X$ ", ela possui fonemas diferentes nas palavras "táxi", "exceção" e "xícara". Mas o mesmo fonema do "X" em "xícara" pode também ser escrito como "CH" ou "SC" em outras palavras da língua portuguesa, dependendo de regras que, para a fala, são irrelevantes.

Os termos "êmico" e "ético" adquiriram um significado ampliado na teoria linguística de Kenneth Lee Pike. Segundo Pike (1954), somente os falantes nativos dominam as descrições êmicas de seu idioma, ou seja, conseguem observar o significado total em contextos complexos que necessitam dessa aproximação mais íntima. Estrangeiros podem absorver as estruturas linguísticas e seus fonemas com maestria, mas nunca dominarão esses contextos complexos como 
os nativos. Um exemplo são certas entonações e expressões idiomáticas, que perdem sentido para quem aprende a língua como um segundo idioma, por mais que conheça cada palavra que constitui a frase.

Pike posteriormente aplicou sua distinção aos estudos do comportamento humano:

Descrições ou análises do ponto de vista ético são externas, com critérios alheios ao sistema. As descrições êmicas fornecem uma visão interna, com critérios escolhidos de dentro do sistema. Representam a visão de alguém familiarizado com o sistema e que sabe como operar dentro dele (PIKE, 1999, p. 29, tradução minha).

Outras humanidades se interessaram por essa classificação para diferenciar métodos mais indutivos de métodos mais dedutivos de interpretação. Metodologicamente, Pike (1999, p. 28) descreveu que a perspectiva ética tende a estar mais afinada aos estudos comparativos, pois as categorias são usualmente criações a priori, externas ao objeto estudado. Já a abordagem êmica precisa de permissão metodológica para que as categorias emirjam do próprio objeto, como descobertas a posteriori.

Na ciência da religião, os termos "êmico" e "ético" foram aplicados pela primeira vez por Johannes Gerhardus Platvoet (1982), embora distinções similares entre perspectivas intrarreligiosas e extrarreligiosas já estivessem presentes em textos anteriores da área (p. ex. SMART, 1973a). Platvoet (1982) adotou a noção de que a narrativa ética seria a que descreve os eventos observados pela perspectiva do pesquisador, enquanto a descrição êmica seria feita pelo olhar dos religiosos. Considerando que a teologia representa a perspectiva de uma tradição, e sob a égide de que a ciência da religião deveria se distanciar do método teológico, classificou-se a forma de construção discursiva teológica como êmica, e a produção dos cientistas da religião como ética.

Embora as nomenclaturas "êmico" e "ético" não sejam populares no Brasil, sua lógica está presente no próprio documento de nossa Área de Avaliação da CAPES, quando é apresentada a distinção entre os profissionais cientistas da religião e teólogos. Nesse documento, um cientista da religião é definido como alguém que estuda as religiões em perspectiva externa, ao passo que os teólogos são definidos como aqueles que promovem seus estudos a partir da perspectiva interna de uma religião (CAPES, 2019, p. 4-5). Na prática, a diferença que esse documento fornece é a mesma apresentada por Platvoet. 
Mas o que significa falar externamente de uma religião? Para Smart (1973a, p. 43-44), as explicações intrarreligiosas recorrem à conexão de diferentes aspectos da dimensão religiosa com outros aspectos da própria religião, como correlacionar a experiência religiosa com padrões devocionais, explicar os ritos pelos mitos ou justificar a fé pelos textos sagrados. Explicações extrarreligiosas, por outro lado, mostram que as religiões também são moldadas por estruturas que não fazem parte de seu domínio imediato. Smart cita exemplos de sistemas étnico-sociais que são reproduzidos em mitos, e também a crença em deusas-terra, que pode surgir como reflexo à descoberta da agricultura. Usualmente os fiéis não possuem noção dessas influências, portanto tais leituras são incomuns ao discurso êmico (PLATVOET, 1982, p. 6).

Mas na ciência da religião,

os resultados finais da pesquisa acadêmica devem ser expressos em linguagem ética, e formulados de modo que permitam críticas e falsificação tanto pela referência ao material êmico quanto por sua coerência e consistência no contexto do discurso ético geral (HANEGRAAFF, 1996, p. 6-7, tradução minha).

Isso significa que uma pesquisa em ciência da religião precisa fazer análises que extrapolem a simples reprodução do discurso dos fiéis, senão acabaria sendo ciência para a religião, e não ciência sobre a religião. Mas isso não significa que o discurso êmico deve ser descartado. Como explica Platvoet (1982, p. 5), a compreensão dos fiéis constitui uma fonte primária importante. Todavia, ela não dá conta das dimensões políticas, étnicas, regionais, culturais, sociais, econômicas, de gênero e ambientais que moldam as religiões para além da crença dos praticantes. É por isso que a fonte êmica precisa ser complementada com a discussão desses fatores extrarreligiosos que moldam significativamente e se inter-relacionam com a religião estudada.

Isso significa que amplas abstrações desses contextos, em busca de um maior paralelismo entre religiões diferentes, não podem ser toleradas. Embora a fenomenologia da religião tenha historicamente recorrido a tais generalizações em seus estudos comparados, essa autocrítica pode ser encontrada mesmo entre autores clássicos dessa abordagem (p. ex. Raffaele Petazzoni, Geo Widengren, Jacques Waardenburg). Por isso, essa é uma postura que deve ser superada, pois retira o caráter científico da ciência da religião, diminuindo a qualidade empírica pela qual os fatos são examinados (PLATVOET, 1982, p. 6). 
A ciência é um sistema de atividades caracterizado por uma postura de "ceticismo organizado", no qual cientistas criticamente escrutinam os materiais de seus pares. Como refutar um argumento se ele for tratado como uma manifestação divina (p. ex. o sagrado que se manifesta)? A adoção da escrita ética permite um melhor controle das metodologias empregadas e das teorias que embasam a pesquisa, por deixar claro que tais perspectivas são externas ao campo de crença de onde os dados foram coletados. Além disso, clarifica materialmente por quais critérios as análises são feitas (PLATVOET, 1982, p. 6).

Por fim, embora o discurso êmico seja nativo às pessoas do grupo do qual ele se origina, internamente ele não é empregado como objeto de estudo. Embora os falantes nativos sejam extremamente proficientes em seus idiomas, há uma distinção clara entre linguistas e falantes. Do mesmo modo, ser praticante não torna alguém dominador das teorias e métodos de estudo de sua religião. Como explica McCutchen (1999, p. 17, tradução minha), "mesmo se o linguista for falante nativo, há uma diferença entre simplesmente utilizar um idioma e discutir, sistematizar e comparar essa utilização. Assim, parece que mesmo os insiders podem se tornar outsiders". Isso é importante, pois a adoção da perspectiva ética não impossibilita um pesquisador de estudar a sua própria religião. Contudo, na ciência da religião o produto final deve transcender os limites êmicos da confissão religiosa pessoal do cientista da religião.

\section{O AGNOSTICISMO METODOLÓGICO}

O agnosticismo metodológico é um importante constituinte de fronteira disciplinar em ciência da religião, referindo-se a uma desconsideração metodológica sobre a "verdade última" das religiões. É uma recusa consciente de confirmar ou refutar o conteúdo "sobrenatural" das religiões, pela justificativa de que essa dimensão não pode ser acessada empiricamente por métodos científicos, e portanto cientistas da religião nada podem dizer a seu respeito (CRUZ, 2013, p. 44). Com o agnosticismo metodológico, as religiões são examinadas apenas como construções humanas. São ignoradas as alegações de seus fiéis de que suas crenças são revelações, os clamores de que seus caminhos são os únicos verdadeiros, de que seus mitos e textos sagrados são fatos, e compreensões de que as posturas religiosas são "naturais", mesmo quando problemáticas socialmente, porque “assim Deus diz" (p. ex. nos casos da religião legitimar desigualdades, fanatismos, intolerâncias e crimes). 
O termo "agnosticismo metodológico" foi cunhado originalmente pelo cientista da religião Roderick Ninian Smart (1973b, p. 54-73) como uma resposta à ideia de "ateísmo metodológico" proposta por Peter Berger (1985, p. 112, 186). Embora Smart tenha proposto o termo como uma crítica a Berger, as explicações desses dois autores sobre o que seria ateísmo/agnosticismo metodológico são bastante similares, podendo ser consideradas análogas (cf. SHEEDY, 2016).

Em primeiro lugar, ateísmo/agnosticismo metodológico não é sinônimo de ateísmo ou agnosticismo. É simplesmente uma postura de se trabalhar com as religiões como produtos da atividade humana. Ao contrário de um convite ao ateísmo ou ao agnosticismo, trata-se de um delimitador de fronteira disciplinar entre a ciência da religião e a teologia (BERGER, 1985, p. 185-186; SMART, 1973b, p. 111). Embora os resultados de pesquisas empíricas sobre as religiões possam ser adotados pela teologia, o tipo de construção de saber teológico é diferente do tipo de saber que a ciência da religião se propõe a produzir.

Um paralelo similar, que facilita a compreensão de como funciona uma fronteira disciplinar, ocorre nas ciências biológicas. Um biólogo pode acreditar na gênese bíblica, mas não pode utilizar profissionalmente o criacionismo e ainda ter seu trabalho reconhecido como pertencente à biologia, pois o criacionismo extrapola a fronteira disciplinar da biologia. O criacionismo não se enquadra nos limites do que academicamente se entende por ciências biológicas.

Entretanto, isso não significa que o agnosticismo metodológico refuta o discurso êmico. Ele simplesmente o coloca em suspensão por não dispor de ferramentas analíticas que permitam considerações a seu respeito. Como esclarece Berger (1985, p. 186), “dizer que a religião é uma projeção humana não implica logicamente que os sentidos projetados não possam ter um status último independente do [ser humano]". Apenas não está entre as preocupações da ciência da religião, enquanto disciplina, validar ou desmentir as considerações sobre o metaempírico presentes no discurso êmico (SMART, 1973b).

Originalmente Berger escreveu sobre o ateísmo metodológico para contestar uma perspectiva, que dominava na academia europeia, de que as respostas em pesquisas sobre as religiões deveriam sempre partir de teólogos. Berger rejeitava a noção de que um cientista apenas deveria "levantar" questões, deixando ao discurso êmico a palavra final em suas pesquisas sobre 
as religiões. Como para ele a sociologia da religião era uma ciência empírica, Berger concluiu que era ilógico que perguntas oriundas de um método empírico obtivessem respostas em um quadro de referência não empírico como o da teologia (BERGER, 1985, p. 185). Portanto, qualquer pesquisa empírica sobre as religiões precisaria estar impreterivelmente baseada no ateísmo metodológico (BERGER, 1985, p. 112).

Considerando que a palavra "ateísmo" possui uma forte carga social, Smart (1973b, p. 5457) sugeriu que o termo talvez não fosse o mais apropriado para a ciência da religião, visto a disciplina prezar por uma isonomia de tratamento às diferentes tradições religiosas. Desse modo, Smart defendeu que o agnosticismo metodológico seria uma atitude mais coerente entre a pressuposição de que Deus é um fato, como ocorre na teologia, e uma pré-concepção de que Deus não existe, como Smart entendeu que Berger preconizou; mesmo que o próprio Berger tenha esclarecido que não era disso que se tratava sua proposta original ( $c f$. BERGER, 1985, $\mathrm{p}$. $112,186)$.

Essa compreensão equivocada de que o ateísmo metodológico seria uma metodologia que de antemão supõe que tudo o que está no mundo metaempírico não existe é, usualmente, a forma como seus críticos lhe descrevem. Porpora (2006, p. 57-58), por exemplo, diz que como o ateísmo metodológico está pautado em uma visão naturalista de mundo, ele dificulta o estudo das experiências religiosas, porque a dimensão putativa da fé, o sobrenatural, é considerada como inexistente. Para Porpora, o agnosticismo metodológico abriria margem para que essa dimensão sobrenatural fosse vista como possível, e por isso seria um método mais adequado.

Essa alegação é refutada por Matt Baldwin (2016 apud SHEEDY, 2016, p. 302-303), quem explica que tanto o ateísmo metodológico quanto o agnosticismo metodológico não admitem explicações mágicas aos fenômenos religiosos. Nem Berger, nem Smart desejavam observar o sobrenatural. Pelo contrário, ambos queriam evitar esse domínio. Portanto, não é que a dimensão sobrenatural seja considerada inexistente ou possível. Ela sequer é considerada. Nenhum dos dois métodos permite conclusões que presumam fenômenos não observáveis. Constatar que a ressurreição de Jesus é uma crença entre os cristãos (algo observável) não abre margens, tanto pelo ateísmo quanto pelo agnosticismo metodológico, a conclusões de que um ser humano objetivamente possa ter levantado dos mortos (algo não observável). Baldwin conclui que optar pelo ateísmo ou pelo agnosticismo metodológico não interfere no resultado final da 
pesquisa, pois sua distinção é filosófica, e não metodológica. Ambas as posturas recorrem a um esquema explicativo naturalista, que sempre ignora metodologicamente a dimensão sobrenatural.

A filosofia da religião também tende a tecer críticas ao agnosticismo metodológico. Cantrell (2016, p. 385), por exemplo, declara que o ateísmo metodológico revela apenas o mundo como ele é, e que o agnosticismo metodológico ignora o significado moral e existencial da relação com Deus, defendendo que seria uma obrigação de todo pesquisador das religiões abordar a questão moral. Já Pondé (2001, p. 42, 45, 55-70) considera o agnosticismo metodológico uma mutilação da religião, um sintoma de falta de "tato religioso", compara quem o utiliza com cegos tentando descrever cores, com pavor das experiências religiosas, e alega que pesquisadores insiders são perseguidos pelos empiristas.

Apesar de críticas similares serem utilizadas no Brasil como justificativas por quem quer estudar suas próprias religiões pela perspectiva êmica, deve-se ter claro que nem Cantrell nem Pondé são cientistas da religião. Cantrell é filosofo, seu escopo metodológico está alinhado à filosofia, e o principal objeto de sua carreira é o papel da religião para a filosofia, nunca com foco na ciência da religião. Já a crítica de Pondé não cita qualquer exemplo empírico do que ele considerou como pavor dos cientistas das religiões das experiências religiosas, o que faz de seu discurso algo retórico, não empírico, estando justamente para além do limite disciplinar estabelecido por Berger e Platvoet.

Ter isso em mente facilita entender porque tais críticas não fazem sentido para a ciência da religião, embora talvez possam ser pertinentes na filosofia. O cientista da religião Zeba Crook (2016 apud SHEEDY, 2016, p. 296), comenta que

uma zoóloga não pergunta a um elefante como é ser elefante; ela estuda o elefante. Um biólogo não tenta imaginar a experiência de um sapo antes de dissecá-lo e tentar entender como ele funciona. As religiões podem ser estudadas analiticamente, eticamente, de fora, como em qualquer outra disciplina analítica. Elas também podem ser estudadas como um membro, adepto e praticante, honrando as experiências de seus companheiros simpatizantes e suas reivindicações internas de autoridade. Mas essa é uma disciplina totalmente diferente da ciência da religião. Não se trata de neutralidade, mas de fronteiras disciplinares.

De acordo com Usarski (2013, p. 51), cientistas da religião limitam-se aos aspectos históricos e materiais das religiões. Em vez de debater a existência ou não de Deus, ou a validade moral dos comportamentos religiosos, eles se concentram nos elementos que são acessíveis empiricamente nas religiões, evitando discussões que extrapolam o método científico. Seu 
propósito é estudar os fatos da vida religiosa, sem fazer apologias a uma tradição determinada. Isso não precisa ser observado, por exemplo, na teologia e na filosofia da religião.

Segundo Crook (2016 apud SHEEDY, 2016, p. 299), cientistas da religião não podem operar diferente de outros cientistas. Dizer que a religião é um objeto "diferente" não é uma justificativa aceitável na ciência da religião. Considerar que quem não possui "sensibilidade" para as manifestações religiosas não pode estudar religião, ou que todo estudo de religião deve se debruçar sobre a moral religiosa são questões que estão para além do que a ciência da religião pode, de fato, verificar.

Assim, o agnosticismo metodológico é um reconhecimento de que a ciência da religião possui um limite de até onde pode ir. Uma vez ultrapassado, abordagens de outras áreas são necessárias, e o cientista da religião deve se afastar. Nenhum saber dá conta de tudo. Como explicou Smart (1973b, p. 111), o agnosticismo metodológico é uma condição sine qua non o cientista da religião não faz ciência da religião. Não é uma opção utilizá-lo ou não. É algo inalienável. Se uma pesquisa não se adequada ao agnosticismo metodológico, ela está para além de nossa fronteira disciplinar.

\section{O FATOR DE TENSÃO COM OS FIÉIS}

Quando um cientista da religião publica algo sobre uma religião, o agnosticismo metodológico e a adoção da perspectiva ética levarão a duas consequências inevitáveis: (1) a fala dos fiéis não será reproduzida ipsis litteris, até porque algumas coisas vistas como essenciais ao êmico serão metodologicamente desconsideradas, o que fará com que (2) o resultado da pesquisa seja uma tradução, com novos vocábulos e interpretações que serão estrangeiros ao grupo estudado. Quando os fiéis entram em contato com o produto final, isso comumente gera estranhamentos.

Um exemplo disso é apresentado por Cruz (2013, p. 44, grifos do autor), ao falar sobre o agnosticismo metodológico:

[...] não basta ao cientista da religião dizer algo do tipo "os cristãos consideram que Jesus Cristo é Filho de Deus" como parte da realidade cultural, e tirar consequências daí, mas precisa enfrentar continuamente a afirmação dos cristãos de que "Jesus Cristo é Filho de Deus", como parte da realidade objetiva do mundo [para os cristãos]. 
Como explica Platvoet (1982, p. 6), geralmente os praticantes de uma religião não possuem ciência de que suas religiões são moldadas e determinadas por fatores sociais, históricos, econômicos, políticos, culturais e geográficos. Usualmente a religião é vista por eles como algo dado, levando-os à rejeição das análises éticas e ao agnosticismo metodológico. Tanto Platvoet (1982, p. 6) quanto McCutcheon (1999, p. 17) comentam que em casos mais extremos, o trabalho do cientista da religião poderá, inclusive, ser considerado sacrilégio ou profanação, gerando reações intensas e passionais das lideranças e instituições religiosas.

Esses conflitos têm sido observados mundialmente, e levaram Michael Pye a desenvolver uma teoria metodológica que prevê esse fator de tensão com os fiéis. Essa proposta parte do pressuposto de que as análises éticas, que comparam o discurso êmico com sistemas não previstos pela lógica interna religiosa, apresentarão questões que podem ser recebidas com inquietação pelos adeptos. Portanto, essa tensão é parte da pesquisa em ciência da religião. A variação de seu grau não só é esperada, como pode ser utilizada para verificar a efetividade dos métodos de coleta de dados e a qualidade das análises elaboradas pelo cientista da religião.

Segundo Pye (2009, 2013), embora as pesquisas em ciência da religião possam ser plurimetodológicas, usualmente suas publicações se dividem em duas etapas: (1) uma fase investigativa, cujo foco está em caracterizar e entender o discurso êmico, apresentando os dados referentes ao objeto estudado; e (2) uma fase analítica, que além de explicar os dados levantados, correlaciona-os com outros fatores sociais externos.

Se ele [o fator de tensão com os fiéis] estiver alto durante as etapas de identificação, há algo errado com o método de investigação. Se estiver atipicamente baixo durante as etapas explanatórias, isso pode sugerir que as explanações estejam fracas (PYE, 2009, p. 100).

Isso significa que metodologicamente é esperado na ciência da religião que o meio estudado se sinta satisfeito com a parte descritiva sobre a sua religião. Como a primeira fase da pesquisa diz respeito a apresentar a religião estudada, e a melhor forma de se aprender sobre uma religião é através de seus próprios praticantes, o cientista da religião tende a promover um sentimento de valorização nos fiéis por retratar seu discurso êmico (PYE, 2013, p. 88, 103-104).

Porém essa intimidade é provisória, e a todo tempo certo distanciamento é ensaiado, mesmo se métodos de observação participante forem adotados. "Sem distanciamento, não é possível haver reflexões, análises e interpretações independentes” (PYE, 2013, p. 90, tradução 
minha). Em outras palavras, se o cientista da religião estiver preocupado em agradar as lideranças religiosas e os fiéis, jamais fará verdadeiramente sua análise.

A fase de análises é caracterizada pela adoção do discurso ético. Como explica Hanegraaff (1996, p. 6), a produção em ciência da religião não é êmica. Portanto, não pode ser apenas uma reprodução da fala dos fiéis. O cientista da religião deve recorrer a linguagens, terminologias, distinções, teorias e modelos interpretativos que serão apropriados na academia, mas que são diferentes da compreensão dos praticantes sobre eles mesmos. Com isso, o sentimento de valorização tende a desaparecer (PYE, 2013, p. 103-105).

Normalmente essas duas fases ocorrem em uma mesma publicação. Por exemplo, em uma pesquisa de ciência da religião, uma parte introdutória descreve as categorias êmicas da religião estudada, uma segunda seção apresenta a teoria que embasará a análise, e uma parte final contém as análises éticas em si. Os fiéis podem adorar a primeira parte do escrito, não entender a segunda (principalmente se não fossem eles próprios acadêmicos), e desgostar da seção final.

Para exemplificar como isso ocorre na prática, cito uma pesquisa sobre o budismo no Brasil. Observando que durante a virada do século XXI a mídia brasileira passou a vincular que o budismo estava crescendo no país, o cientista da religião Frank Usarski (2004b) decidiu verificar os dados do censo de 1991 e de 2000, constatando que ao contrário do que a mídia estava divulgando, o IBGE indicava um declínio do budismo. Como resultado, um ministro do Budismo Terra Pura publicou um artigo resposta ( $c f$. GONÇALVES, 2005). Embora se apresente como historiador, ele fala mais como líder budista nesse texto do que como acadêmico. Gonçalves frisa a sua própria experiência religiosa o tempo todo sem um maior distanciamento, faz uma separação entre o "budismo real" (do qual o grupo dele seria um exemplo) e outras formas "não tão puras" de budismo, declara esperança frente ao crescimento da religião no país e, como se esperaria pela metodologia de Pye, critica a pesquisa de Usarski.

Mas apesar do incômodo causado pelos resultados apresentados por Usarski, Gonçalves acabou por considerar os fatos levantados, ainda que sobre críticas ao cientista da religião. Até esse artigo, nunca os números do IBGE haviam aparecido nos textos de seu grupo. Mas a partir da pesquisa de Usarski, o Budismo Terra Pura passou a investir no missionarismo e em traduções de textos chineses e japoneses, visando à difusão do budismo pelo Brasil. Com isso, ao comparar os dados do censo de 2000 com os de 2010, um aumento no número de budistas é notado, um 
possível fruto das reações dos budistas frente à problemática levantada por uma pesquisa da ciência da religião.

Esse caso é emblemático porque permite observar que, para além das duas fases pensadas por Pye, há um terceiro momento nos estudos em ciência da religião que diz respeito ao que o grupo estudado faz com os resultados da pesquisa, algo que independe do pesquisador. Essa reação, que pode ser de ignorar os resultados ou de incorporá-los, permite possibilidades antes não consideradas pelos praticantes, o que pode fortificar seu grupo a médio e longo prazo.

No entanto, é importante perceber que não serão todos os fiéis que necessariamente se incomodarão com os textos da ciência da religião. As religiões são construções coletivas, que são perpetuadas de forma contínua, independendo se determinadas pessoas continuam ou não a fazer parte delas. Além disso, nem todo adepto pensa e pratica a mesma coisa dentro de uma mesma tradição. Isso explica, por exemplo, porque às vezes as próprias lideranças não conseguem direcionar o desenvolvimento e os rearranjos dos complexos simbólicos de sua religião à sua vontade. Esse processo é feito por muitas pessoas, cada qual com seus próprios interesses e motivações. E não necessariamente o interesse de todos será o mesmo do líder.

Pye $(2013,2014)$ elenca alguns motivos mais comuns para o desconforto dos fiéis quando leem uma pesquisa em ciência da religião: (1) o cientista da religião pode levantar questões que não são de interesse dos adeptos sobre suas próprias religiões ${ }^{6}$; (2) o estudo pode mostrar estruturas que antes não eram claras aos fiéis (ou eram apenas parcialmente claras), levando-os a considerar que as análises não estão $\operatorname{corretas}^{7}$; (3) a comparação entre diferentes tradições pode não ser aceita em grupos que pregam que seu caminho é único; (4) ao levantar contextos políticos e socioculturais, a pesquisa pode gerar a necessidade de explicações de determinados discursos das lideranças religiosas que até então poderiam nunca ter sido colocados à prova ${ }^{8}$; e (5) algumas

\footnotetext{
${ }^{6}$ Aqui residem os temas tabus. Um exemplo é comumente observado em pesquisas sobre freiras. Geralmente as freiras não têm qualquer restrição em falar sobre seus votos de pobreza e obediência, mas dificilmente proferem mais do que meia dúzia de palavras sobre seu voto de castidade. A castidade de freiras tende a ser tomada como "óbvia", um tema "resolvido" aos católicos. Portanto, não tem o que se perguntar sobre isso. No outro cenário, pode-se citar o silêncio da igreja católica sobre as denúncias de pedofilia por clérigos, não apenas por não se esperar que um homem de confiança seja criminoso, como também porque o celibato é compulsório a seus sacerdotes.

${ }^{7}$ P. ex., as proximidades ritualísticas entre cultos neopentecostais e cultos de religiões de matriz africana são usualmente recebidas como ofensas pelos evangélicos, porque essa relação não lhes é visível.

${ }^{8}$ P. ex., a escalada política de cristãos no Brasil, defendida e incentivada por vários pastores e padres, visando criar leis para toda a população com base nas crenças e dogmas do cristianismo, em desrespeito à laicidade do Estado e à liberdade religiosa assegurada pela Constituição.
} 
religiões tratam seus textos sagrados e mitos como fatos históricos, o que geralmente não se sustenta por dados empíricos.

Além desses cinco motivos, a valorização de uma autoidentidade monolítica pelas religiões também é apontada por Pye (2013, p. 102-103) como um sexto fator importante. Usualmente os fiéis tendem a falar em "o católico", "o evangélico" ou "o espírita”, como se todas as pessoas que fazem parte de sua comunidade pensassem igual. Contudo, há uma diversidade muito grande de motivações e interpretações entre pessoas de uma mesma religião. Por demonstrar essa pluralidade, a pesquisa em ciência da religião pode enfrentar resistência entre alguns fiéis, que podem acusar o pesquisador de ter selecionado mal seus sujeitos de pesquisa e declarar que seus entrevistados não eram bons representantes (ou não eram adeptos verdadeiros) de sua religião.

Um último ponto que vale a pena ser mencionado diz respeito à naturalização dos papeis sociais de sexo pelas religiões. O maior exemplo disso é a atual resistência que as igrejas cristãs possuem em discutir gênero em qualquer âmbito público da sociedade brasileira. Para as religiões, usualmente os papeis sociais de sexo são vistos como algo dado pela divindade, e as relações desiguais entre os gêneros são justificadas pela religião, em uma lógica de que "assim Deus fez". Se por acaso uma pesquisa questiona tais papeis, demonstrando que eles são construções históricas de poder, inevitavelmente gera resistências. Esse não é um ponto citado por Pye, mas que deve ser encaixado dentro de sua teoria.

\section{CONCLUSÃO}

A tese apresentada nesse artigo é de que embora a ciência da religião possa utilizar vários métodos, todos se inserem em uma estrutura disciplinar com pressupostos básicos que norteiam atitudes metodológicas para seus profissionais. Dentre esses pressupostos, foram mencionados: (1) a distinção entre discursos êmicos e éticos, a observação respeitosa das expressões êmicas, mas com a produção sendo feita por uma abordagem ética sobre o que é estudado; (2) o agnosticismo metodológico, um pressuposto de distanciamento que recusa a afirmar ou negar questões propriamente religiosas, resguardando o cientista da religião somente a análises do que é empiricamente observável; e (3) o fator de tensão com os fiéis e como ele opera ao longo das 
fases na pesquisa em ciência da religião, um aspecto importante para o estudo dos cientistas da religião.

Conclui-se, portanto, que para que uma pesquisa seja considerada da ciência da religião, ela deve ao menos levar em conta esses três pontos-chave. O que constituiria o trabalho do cientista da religião não é a adoção de métodos próprios de análise ou coleta de dados, mas essa abordagem metodológica que guia o paradigma da pesquisa. Em outras palavras, propus neste artigo a existência de algo na ciência da religião que seria similar ao que na antropologia é chamado de "olhar do antropólogo". Independentemente se a pesquisa é empírica ou de revisão, se utiliza entrevistas, questionários, pesquisa participativa ou faz um levantamento de documentos históricos, se sua análise foi dedutiva ou indutiva, se o viés era qualitativo, quantitativo ou misto, é o paradigma de pesquisa pautado nos três pontos supramencionados o que identifica um trabalho como sendo parte da construção intelectual da ciência da religião.

\section{REFERÊNCIAS}

ALLES, G. D. (Ed.). Religious studies: a global view. New York: Routledge, 2008.

BERGER, P. L. O dossel sagrado: elementos para uma teoria sociológica da religião. São Paulo: Paulus, 1985.

CAPES. Área 44: ciências da religião e teologia. Documento de área. Brasília: MEC, 2019.

CARVALHO, F. R. História das religiões seria história ou ciência da religião? Uma reflexão sobre questões metodológicas ligadas a essas disciplinas na transição dos anos 1860-1870. Sacrilegens, Juiz de Fora, v. 14, n. 1, p. 31-50, 2017.

CRUZ, E. R. Estatuto epistemológico da ciência da religião. In: PASSOS, J. D.; USARSKI, F. (Orgs.). Compêndio de ciência da religião. São Paulo: Paulus; Paulinas, 2013, p. 37-49.

DURKHEIM, E. As regras do método sociológico. 9a ed. São Paulo: Nacional, 1978.

ELIADE, M. The quest: history and meaning in religion. Chicago: University of Chicago, 1969. . O sagrado e o profano. São Paulo: Martins Fontes, 1992.

ENGLER, S. Brazil. In: ALLES, G. D. (Ed.). Religious studies: a global view. New York: Routledge, 2008, p. 273-277. 
FRAZER, J. G. O escopo da antropologia social. In: CASTRO, C. (Org.) Evolucionismo cultural: textos de Morgan, Tylor e Frazer. Rio de Janeiro: Zahar, 2005, p. 101-127.

GASBARRO, N. M. Fenomenologia da religião. In: PASSOS, J. D.; USARSKI, F. (Orgs.). Compêndio de ciência da religião. São Paulo: Paulus; Paulinas, 2013, p. 75-113.

GONÇALVES, R. M. As flores do dharma desabrocham sob o Cruzeiro do Sul. Revista USP, São Paulo, n. 67, p. 198-207, 2005.

HANEGRAAFF, W. J. Introduction. In: New Age religion and Western culture: Esotericism in the mirror of secular thought. Leiden: Brill, 1996, p. 1-20.

2017. . Definindo religião, apesar da história. Religare, João Pessoa, v. 14, n. 1, p. 202-247,

McCUTCHEON, R. T. General introduction. In: (Ed.). The insider/outsider problem in the study of religion. London: Continuum, 1999, p. 1-11.

MENDES, A. Apontamentos de análise do discurso por uma prática profissional da ciência da religião. In: STERN, F. L.; COSTA, M. O. (Orgs.). Ciência da religião aplicada: ensaios pela autonomia e aplicação profissional.. Porto Alegre: Fi, 2018, p. 15-30.

MURPHY, T. M. Ciência da religião como discurso colonialista: o caso de Rudolf Otto. REVER: Revista de Estudos da Religião, São Paulo, v. 18, n. 1, p. 329-349, 2018.

PIKE, K. L. Language in relation to a unified theory of the structure of human behavior. California: Summer Institute of Linguistics, 1954.

. Etic and emic standpoints for the description of behavior. In: McCUTCHEON, R. T. The insider/outsider problem in the study of religion. London: Continuum, 1999, p. 28-36.

PLATVOET, J. G. Comparing religions: a limitative approach. Den Haag: Mouton, 1982.

PONDÉ, L. F. C. S. Em busca de uma cultura epistemológica. In: TEIXEIRA, F. L. C. (Org.). $A(s)$ ciência $(s)$ da religião no Brasil: afirmação de uma área acadêmica. São Paulo: Paulinas, 2001, p. 11-66.

PORPORA, D. V. Methodological atheism, methodological agnosticism and religious experience. Journal for the Theory of Social Behaviour, Oxford; Malden, v. 36, n. 1, 2006, p. 5775 .

PYE, M. O estudo das religiões e o diálogo entre as religiões. REVER: Revista de Estudos da Religião, São Paulo, v. 9, n. 3, p. 98-119, 2009.

. Getting into trouble with the believers: intimacy and distance in the study of religions. In: _. Strategies in the study of religion: exploring methods and positions. v. 1. Berlin: de Gruyter, 2013, p. 86-106. 
. Methodological integration in the study of religions. Scripta Instituti Donneriani

Aboensis, [S.1.], v. 17, n. 1, p. 189-206, 2014.

SHEEDY, M. Ateísmo metodológico vs. agnosticismo metodológico. Último Andar, São Paulo, v. 1 , n. 29, 2016, p. 295-303.

SMART, R. N. The phenomenon of religion. New York: Herder \& Herder, 1973a.

. The science of religion and the sociology of knowledge: some methodological

questions. Princeton: Princeton University, 1973b.

STERN, F. L. A criação da área de avaliação "ciências da religião e teologia" na Coordenação de Aperfeiçoamento de Pessoal de Nível Superior (CAPES). Espaços, São Paulo, v. 26, n. 1, p. 7391, 2018.

STERN, F. L.; COSTA, M. O. Metodologias desenvolvidas pela genealogia intelectual da ciência da religião. Sacrilegens, Juiz de Fora, v. 14, n. 1, p. 70-89, 2017.

USARSKI, F. Os enganos sobre o Sagrado: uma síntese da crítica do ramo "clássico" da fenomenologia da religião e seus conceitos-chave. REVER: Revista de Estudos da Religião, v. 1, n. 4, p. 73-95, 2004a.

. O dharma verde-amarelo mal-sucedido. Estudos Avançados, São Paulo, v. 18, n. 52, p. 303-320, 2004b.

. História da ciência da religião. In: PASSOS, J. D.; USARSKI, F. (Orgs.). Compêndio de ciência da religião. São Paulo: Paulus; Paulinas, 2013, p. 51-62.

WACH, J. E. A. F. Os ramos ad ciência da religião. REVER: Revista de Estudos da Religião, São Paulo, v. 18, n. 2, 2018, p. 233-253. WIEBE, D. Religious studies. In: HINNELLS, J. R. (Ed.) The Routledge companion to the study of religions. New York: Routledge, 2005, p. 98-124. 